\title{
Followers' Perception of Leadership Style, Organizational Commitment and Regulatory Focus, Moderated by Organizational Types
}

\author{
Roni Mash ${ }^{1} \nsim$ \\ Lihi Cohen ${ }^{2}$ \\ 'Senior Lecturer, the MA Program of Organizational Psychology, Ariel University, Israel \\ Email:ronimash@inter.net.il \\ ${ }^{2}$ Psychologist in Nonprofit Organizations, Israel
}

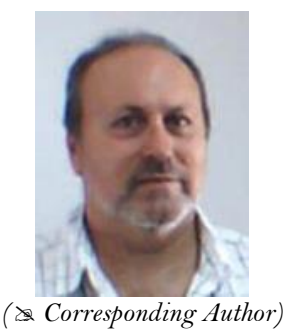

\begin{abstract}
Research hypotheses assumed that a positive connection would be found between transformational leadership, on one hand, and affective commitment and focus on promotion, on the other. It was also assumed that this connection would be stronger in coercive organizations. Furthermore, the research hypotheses assumed there would be positive connections between transactional leadership, on one hand, and continuance commitment and focus on prevention, on the other; stronger in utilitarian organizations. 82 employees of coercive organizations and 80 employees of utilitarian organizations participated in this study using the MLQ questionnaire, an organizational commitment questionnaire, and a regulatory focus questionnaire. It was found that the more a leader is perceived by followers as having a transformational style, the more followers will feel affective commitment toward the organization and the more they will focus on promotion and successes. Moreover, the more a leader is perceived as a transactional leader followers will feel more continuance commitment and be more focused on preventing failures. The moderation model by type of organization was confirmed. Difference between the connections noted above in coercive organizations as compared to utilitarian organizations was found.
\end{abstract}

Keywords: Leadership style, Regulatory focus, Organizational commitment, Organizational types.

Citation | Roni Mash; Lihi Cohen (2018). Followers' Perception of Leadership Style, Organizational Commitment and Regulatory Focus, Moderated by Organizational Types. Asian Journal of Socia Sciences and Management Studies, 5(3): 137-146. History:

Received: 7 June 2018

Revised: 19 July 2018

Accepted: 14 August 2018

Published: 27 September 2018

Licensed: This work is licensed under a Creative Commons Attribution 3.0 License (c))

Publisher:Asian Online Journal Publishing Group
Contribution/Acknowledgement: Both authors contributed to the conception and design of the study.

Funding: This study received no specific financial support.

Competing Interests: The authors declare that they have no conflict of interests.

Transparency: The authors confirm that the manuscript is an honest, accurate, and transparent account of the study was reported; that no vital features of the study have been omitted; and that any discrepancies from the study as planned have been explained.

Ethical: This study follows all ethical practices during writing.

\section{Contents}

1. Theoretical Background

2. Research Model

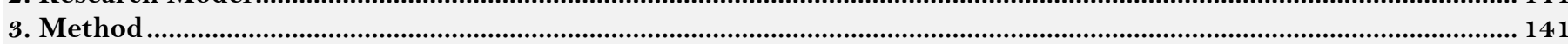

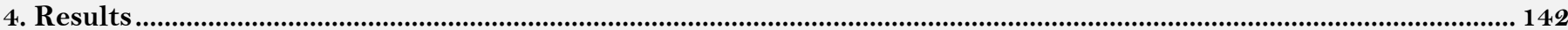

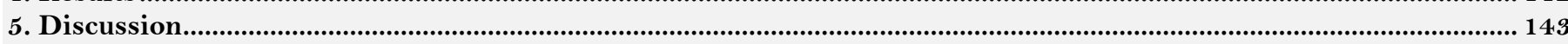

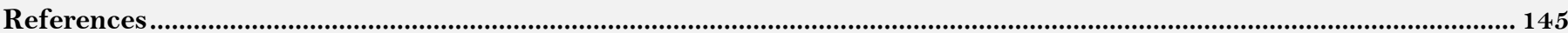




\section{Theoretical Background}

\subsection{Transformational Leadership and Transactional Leadership}

The professional literature on the subject of leadership from the 1990s defines leadership as a process of social influence whose effectiveness depends on the extent to which followers perceive the individual as a valid source of influence (Lord and Maher, 1993; Meindl, 1995; Banks et al., 2016; Bernerth et al., 2017).

Burns (1978) identified two types of leadership styles: Transformational leadership and transactional leadership. Burns viewed the transactional leader as one who is perceived as initiating contact with his subordinates, in an effort to exchange something of value, such as: rewards for performance, mutual support or two-sided exposure. The transformational leader, according to Burns (1978) is one who brings about increased motivation and morale of followers through affective efficacy, without followers expecting any material reward whatsoever. Burns (1978) claimed that leaders can be classified according to their leadership style: a style that tends toward transactionality, as opposed to a style that strives to shape followers.

Avolio and Bass (1991) presented an empirical study that mapped out common leadership styles among military officers and managers. They situated Burns (1978) transformational leadership and transactional leadership on a continuum. This model is called the "Full Range of Leadership" model. The structures that comprise the model represent three types of leadership styles: Transformational leadership, transactional leadership, and the 'laissez-faire' style, which are represented by nine different factors.

The 'laissez-faire' style is described in the above model as either a lack of leadership, avoidance of any intervention whatsoever, or both of these together. In this avoidance style of leadership, there is no expression of negotiations with followers, decisions are usually postponed, and rewards, interventions, and feedback are absent. Furthermore, there is no engaged attempt to improve followers' motivation and satisfaction (Avolio and Bass, 1991). This leadership style tends to be characterized by avoidance of playing the role of leader, and offers very little direction and support (Kirkbride, 2006).

According to the abovementioned model, a transactional leader acts within the existing system and culture, prefers to avoid risks, devotes attention to restrictions of time and efficiency, and generally prefers process to content as a means to preserve control and supervision (Bass, 1985). A leader of this type uses an active form of management by testing and observing workers' errors and correcting them immediately (Northouse, 2007). The transactional leader establishes norms and means to measure followers' behavior, and then observes followers to avoid deviations and errors. The leader sets objectives and clarifies his/her expectations of followers, so the organization will achieve the desired results (Avolio and Bass, 2004). A connection has been found between transactional leadership and the building of a basic level of trust, due to clarification of expectations and rewards for workers (Bass et al., 2003). Furthermore, a connection has been found between transactional leadership and efficiency (Martin, 2015).

Transformational leadership is characterized by seeking new work approaches; striving to find opportunities among risks; a preference for efficient solutions; and only a limited tendency to preserve the status quo. A transformational leader not only responds to environmental circumstances, but fashions and creates them himself (Bass and Avolio, 1990). This type of leadership relates to a leader who motivates followers beyond immediate selfinterests (Erkutlu, 2008). Transformational leadership has significant impact on both the personal and organizational levels. On the personal level, transformational leadership is connected positively with work satisfaction (Dumdum et al., 2002) organizational civic behavior (Piccolo and Colquitt, 2006) commitment to the organization (Judge and Piccolo, 2004) and worker creativity (Gumusluoglu and Ilsev, 2009). On the organizational level, transformational leadership is positively connected with organizational innovativeness, worker performance (Judge and Piccolo, 2004) worker output, and organizational profitability (Lowe et al., 1996).

\subsection{Organizational Commitment and Full-Range Leadership}

Organizational commitment is the "psychological bond" with the organization that influences the worker and causes him/her to behave consistently with the organization's interests (Riketta, 2002; Bentein et al., 2005). According to Griffin and Hepburn (2005) understanding commitment to the organization and its advancement is essential for organizational efficiency and efficacy.

Allen and Meyer (1996) pointed out three types of organizational commitment: continuance commitment, which relates to an instrumental connection expressed by awareness of the costs involved with leaving the organization; affective commitment, which relates to an emotional connection that is expressed through the worker's identification and involvement with the organization; and normative commitment, defined as a state in which the worker remains bound up with the organization, out of a sense of obligation and necessity to remain at the workplace, since that is the proper and right thing to do.

Mcgee and Ford (1987) identified two dimensions in continuance commitment: a lack of possible alternatives and a perceived sacrifice of resources connected with leaving the organization. It has been found that continuance commitment increases as resources invested in the organization increase, and alternative possibilities decrease (Rusbult and Farrell, 1983).

Relatively recent studies have found that workers' and managers' ethical behavior and perceived support from the organization increase workers' affective commitment (Fu et al., 2011). When development of a mutual relationship occurs between the worker and the organization, the worker develops affective commitment that increases his/her sense of obligation to reciprocate concern for the organization's support, simultaneously providing for the worker's needs, such as attachment and affective support (Rhoades and Eisenberger, 2002).

It has been found that workers who experience affective commitment toward an organization have a sense of attachment and organizational identity that increases their involvement in the organization's activities, their readiness to attain organizational goals, and their desire to remain in the organization (Mowday et al., 1982; Meyer and Allen's, 1991).

The factor thought to influence organizational commitment most is the leadership style of a worker's direct manager (Mowday et al., 1982). Prominent research in this context indicates that transformational leadership is positively connected with organizational commitment, both in different types of organizations as well as in 
different cultures (Koh et al., 1995; Lowe et al., 1996; Dumdum et al., 2002; Bono and Judge, 2003; Walumbwa and Lawler, 2003).

In a study by Buciuniene and Skudiene (2008) examining the connection between leadership and affective organizational commitment, a high correlation was found between these two variables - that is, a positive connection was found between transformational leadership and followers' affective commitment. This finding is not surprising, since transformational leadership is associated with affective aspects. Some even term this leadership style as 'emotion evoking leadership' (Popper, 1994; Popper, 2012). A transformational leader influences the affective commitment of each of his/her followers, encouraging them to think creatively by using innovative methods. Further, a transformational leader relates individually to each worker, involves workers in the decision making process, inspires them, and conveys loyalty to the organization as a paradigm for imitation (Yammarino et al., 1993; Bass and Avolio, 1997; Avolio, 1999)

Based on the above research, a hypothesis was proposed in the current study (Hypothesis 1): that a positive connection will be found between transformational leadership, as perceived by followers, and followers' affective commitment to the organization, such that high levels of transformational leadership would predict high levels of affective commitment to the organization.

A transactional leader devotes attention to time limitations and efficiency (Bass, 1985) as well as using an active form of management by examining and observing workers' mistakes and correcting them immediately (Northouse, 2007).

The tendency of followers who are subordinate to a transactional leader will be to act in accordance with a system of 'give and take.' It is reasonable to assume that they will invest the necessary resources in order to receive compensation, that they will avoid errors, and nothing beyond that. When a better alternative option is found, offering greater compensation, followers will leave the organization. In addition, Lo et al. (2009) found in their studies that the compensation dimension and the active management dimension are significantly related to continuance commitment.

Based on the above studies, we formulated a hypothesis in the present study (Hypothesis 2): that a positive connection will be found between transactional leadership, as perceived by followers, and followers' continuance commitment, such that high levels of transactional leadership would predict high levels of continuance commitment to the organization.

\subsection{Regulatory Focus}

The regulatory focus theory developed by Higgins (1998) describes significant differences between people in a process wherein they advance toward pleasures and avoid pain. Higgins (1998;2001) also distinguished between two types of regulatory focus: promotion focus, characterized by promotion of individuals' private goals, connected primarily with advancement, growth, achievement, aspirations toward attaining an ideal self, and building strategies involved with an enthusiastic pursuit of profits and successes. Prevention focus, on the other hand, is characterized by individuals' private goals connected primarily with avoidance, defense, security and responsibility. The goals of prevention involve avoidance of mistakes and building strategies concerning avoidance of losses and failures.

Promotion focus and prevention focus are conceptual orientations connected with motivational processes for advancement or avoidance. Therefore, a person with a high level of prevention focus will feel motivated toward avoidance, guiding his/her behavior toward a distancing from attaining undesirable things, whereas a person with a high level of promotion focus will experience motivation toward advancement which will guide his behavior toward attaining desirable things (McGregor et al., 2007).

Regulatory focus contains a stable element (trait) and a situational element (state) (Stam et al., 2010). The stable element (trait) describes the individual's personal inclination to be focused on promotion or focused on prevention. The source of this inclination is associated with interactions with significant others during childhood. The situational element (state) indicates that a person's environment can bring about a specific regulatory focus: for example, when a person works in an environment that induces an atmosphere of future profit, that person will have a stronger inclination toward focus on promotion at work (Higgins and Silberman, 1998).

Prevention focus is connected with a local (in contrast to a global) perception (Förster and Higgins, 2005) and with analytical thinking (Seibt and Förster, 2004). It has been found that people with a prevention focus will prefer to renew a task that was stopped, and not to begin a new task, as well as to preserve the objects in their possession (Liberman et al., 1999). Focus on promotion causes people to worry about their personal growth and their developmental needs. Individuals with high promotion focus will be motivated to attain goals that represent their beliefs or their ideal self (Brockner and Higgins, 2001). It has been found that an individual's focus on promotion has an important role, mediating between a perspective of the future and motivations for growth at work. Thus, a worker with high promotion focus will see himself advancing in the organization in the long term (Kooij et al., 2014). Furthermore, it has been found that promotion focus is likely to increase the worker's affective commitment to the organization. This commitment develops primarily in the wake of the organization's support for the person's growth and aspirations (Neubert et al., 2008).

\subsection{Leadership and Promotion Focus}

A transformational leader is characterized by motivating his/her followers to do more than they expected of themselves or than what was expected from them (Bass, 1985). Therefore, the leadership style of a leader, as perceived by followers, is likely to contribute to their level of promotion focus. For example, when a leader supports, directs, empowers, encourages and shapes the follower toward attaining lofty goals, the follower will feel focused on promotion. Evidence of this is found in the theoretical model of Kark and Dijk (2007) which indicates that transformational leadership arouses promotion focus since it is connected, among other things, to ambition and inspired motivation of followers.

A transformational leader who motivates his/her followers beyond their expectations, will induce an atmosphere of striving for personal achievements, and thus in the present study we hypothesized that (Hypothesis 
3): a positive connection will be found between transformational leadership, as perceived by followers, and focus on promotion of followers, such that high levels of transactional leadership will predict high levels of promotion focus.

Transactional leadership encourages followers to perform their work in terms of strategic means, rules, responsibility, stability, avoidance of mistakes and short-term planning (Bass, 1985). Since prevention focus is characterized by avoidance, protection, security and responsibility, we may conclude that transactional leadership encourages followers to focus on prevention in their work. Evidence of that is found in the theoretical model of Kark and Dijk (2007). Transactional leadership arouses prevention focus, since, among other things, it is connected with duties and rights, preservation of the status quo and strict attention to detail.

A transactional leader who inculcates in his/her followers values of stability and short-term focus, will encourage an organizational culture of preserving the status quo and avoiding mistakes, and therefore the current study assumes that (Hypothesis 4): a positive connection will be found between transactional leadership, as perceived by followers, and followers' prevention focus, such that high levels of transactional leadership will predict high levels of prevention focus.

\subsection{Coercive Organizations, Utilitarian Organizations and their Leadership Context}

The purpose of systematic classification of organizations is to improve our ability to understand and explain the factors that influence the formation of structures and the occurrence of organizational processes. Classification is based on either the analytic method that infers from the general to the specific, or on the empirical method that infers from the specific to the general phenomenon. The analytic method attempts to identify theoretically, a basic characteristic shared by any group of individuals that makes these individuals distinct from others, and enables classifying them as a specific "type" (Samuel, 2012). Thus, for example, Blau and Scott (1962) developed a typology for classification of organizations based on the criterion: Who is the primary beneficiary of the existence of a given organization? Their basic assumptions revolve around the idea that every organization produces different benefits for a broad variety of individuals and groups or the whole society, and that each organization has defined goals it is intended to realize.

Katz and Kahn (1966) developed a typology for classifying organizations, based on the concept of an organization as an open social system, according to which each organization is a subsystem of a broader social system, and the basis of classification is the primary contribution of each organization to broader human society, in a framework of products and services.

Etzioni (1961) also pointed out a typology for classifying organizations, based on two assumptions: The first assumption is that organizations are based on the application of power upon people. The second assumption states that organizational activity is feasible only if people at the lowest level of the organization, accept the authority of the organization's managers and obey their instructions. The latter typology is based on leaders' power and the forms of identification and involvement of the lowest echelon in the organization. According to Etzioni, every organization maintains order and discipline through one of the following types of power that are available to those in charge: physical power - expressed through use of threats and application of corporal punishments; economic power - expressed through use of granting or withholding material rewards; moral power - expressed by use of legal, religious, and ethical means. People of the lowest echelon accept the authority of superiors, cooperate and carry out what is required from them, due to one of the following motives: alienation - fear of being punished leads to obedience out of necessity, not out of identification; utilitarian considerations - economic motives cause acceptance of authority on a basis of cost and benefit considerations; identification - belief in the organization's values causes identification with its goals, the values of its activity, and faith in the organization's leaders. According to Etzioni (1961) these characteristics create a typology that includes several types: Coercive organizations - in which rules of behavior are enforced physically, achieve obedience but with a good deal of alienation (prisons, army, police station). Utilitarian organizations - operate on a basis of mutual profitability of leaders and followers, who are interested in ensuring material benefits for themselves from the organization's activity (business organizations). Identity organizations - operate on a basis of mutual identification with social values as represented by leaders and internalized by followers (for example, churches voluntary organizations). The present study focuses on coercive organizations and on utilitarian organizations, and its purpose is connected with investigating the manner in which authority is accepted by followers in each type of these organizations. How, then, are the organizations of the types noted above connected with transformational leadership and transactional leadership?

Gonen and Zakkai (1999) defined transformational leadership as a type of leadership in which the leader strives to increase his/her people's awareness of correct, important things as he sees it, and to provide meaning to what they do. By providing meaning, people feel more capable and strengthened in attaining common objectives. Formative leadership brings people to higher achievements than they recognize and expect of themselves. The sense of meaning brings about spiritual elevation and ultimate investment toward achieving shared goals.

Popper (1994) argued that in military organizations, where soldiers are required to invest extreme physical and emotional efforts, at times life-endangering, there is an emphasis on motivating subordinates through influence, without needing authority or power. In a simple, small scale organization, the usual coordination is perceived as direct supervision, mutual coordination, or a combination of both. In large organizations there is room for standardization of organizational processes (Mintzberg, 1979). Organizations included in the coercive type (army, police, prison) are large organizations typified by a large measure of standardization of organizational processes. Findings show that organizations characterized by an intensive degree of process standardization are also characterized by a great deal of administrative concentration (Mintzberg, 1979). Popper (1994) demonstrated this with military organizations, claiming that the military leader is characterized by expertise in the task field, and that his expertise is at times anchored in his experience, so that he sometimes senses what the right thing to do is.

With regard to the research literature, we may assume that the leader in a coercive organization will be an expert in the task field due to high standardization, will set a personal example for his followers, will provide a sense of meaning for their work, and will place emphasis on motivating subordinates through influence, similar to the transformational leadership style. Therefore, a hypothesis has been derived in the present study (Hypothesis 5): 
that the 'organization type' will constitute a moderating variable, and will influence the strength and intensity of connections with leadership style, as follows: In coercive organizations, stronger connections will be found between transformational leadership and affective commitment than in a utilitarian organization. Similarly, in coercive organizations, stronger connections will be found between transformational leadership and promotion focus than in utilitarian organizations.

Utilitarian organizations are characterized by promising material benefits from the organization's activity, for both followers and leaders (Etzioni, 1961). The high-tech industry, for example, according to Popper (1994) which is characterized by an abundance of information, attributes great importance to knowledge, so that more flexible and less standard forms of work are created. The manager in these organizations essentially operates systems of experts to perform tasks characterized to a great extent by complexity, to the point that the manager lacks the knowledge to manage the tasks. For that reason, he requires decentralization in his basic approach.

The transactional leader establishes norms and means to measure followers' actions, and after that observes followers in order to ascertain lack of deviations and mistakes. He sets objectives and makes his expectations of followers clear, so that the organization will attain the desired results (Avolio and Bass, 2004). Moreover, he must act efficiently to that end (Martin, 2015). If so, it is reasonable to assume that a leader in utilitarian organizations will use reward methods, objectives and observation similar to those characteristic of transactional leadership, in order to attain his goals. His followers will comply in order to receive the material benefits when meeting the objectives. Therefore, we proposed a hypothesis in the present study (Hypothesis 6): that 'organization type' will constitute a moderating variable, and will influence the intensity and strength of connections with leadership style. This means that in a utilitarian organization, stronger connections will be found between transactional leadership and continuance commitment than in a coercive organization; and that in a utilitarian organization, stronger connections will be found between transactional leadership and prevention focus than in a coercive organization.

\section{Research Model}

The 'organization type' variable will mediate the connection between the 'leadership type' variable and the 'organizational commitment' variable. In a coercive organization the positive connection between transactional leadership and affective commitment will be stronger than in a utilitarian organization. In a utilitarian organization the positive connection between transactional leadership and continuance commitment will be stronger than in a coercive type organization (See Figure 1).

Furthermore, the 'organization type' variable will moderate the connections between the 'leadership type' variable and the 'regulatory focus' variable. In a coercive organization, the positive connection between transformational leadership and promotion focus will be stronger than in a utilitarian organization. In a utilitarian organization, the positive connection between transactional leadership and prevention focus will be stronger than in a coercive organization.

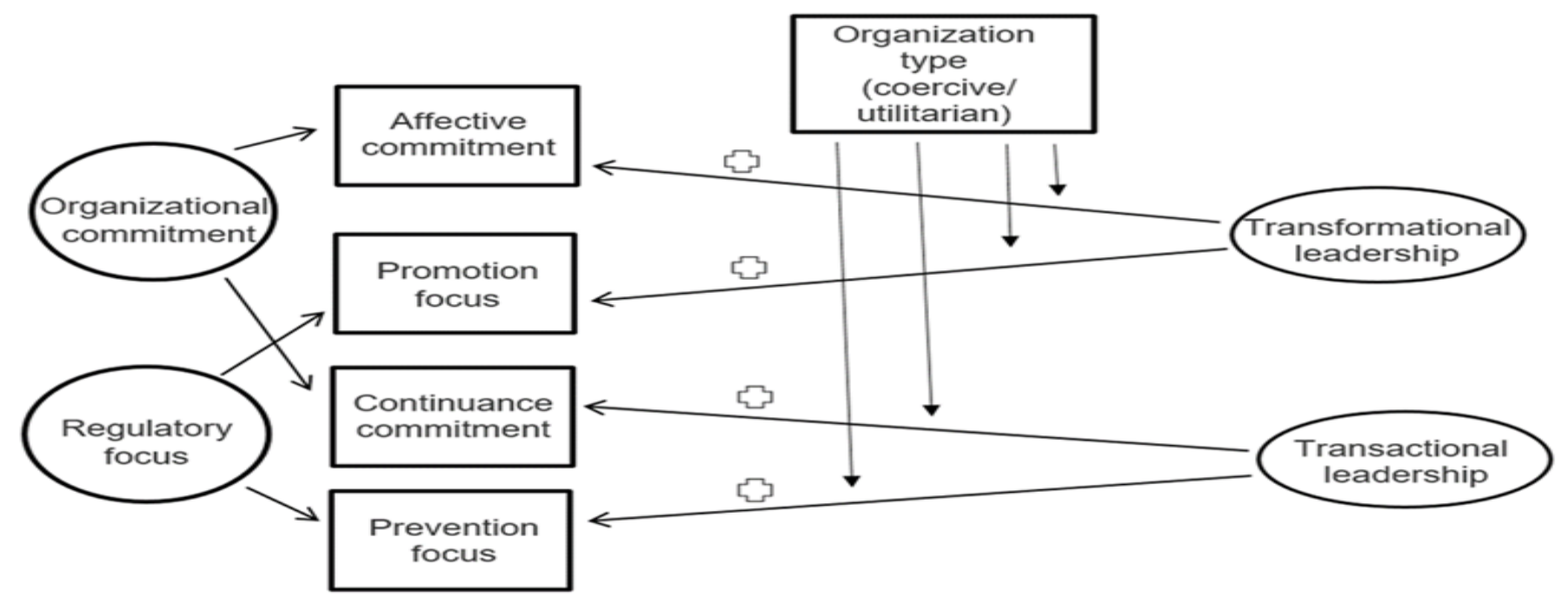

Figure-1. Research model: Positive connection between leadership type (transformational, transactional) and organizational commitment (affective, continuance) and followers' regulatory focus (promotion, prevention) moderated by organization type (coercive, utilitarian).

\section{Method}

\subsection{Sample}

Participating in the study were 82 workers in coercive organizations and 80 workers in utilitarian organizations, totaling 162 participants, $59 \%$ men and $41 \%$ women. The average age of subjects was 30, with S.D. 7.6. Average participants' seniority at position was 33 months, S.D. 39.4, and average seniority in the organization was 53 months, S.D. 63.5. Subjects were chosen according to the following criteria: at least a half year in the position, at least half time.

\subsection{Research Instruments}

In order to examine leadership style we used the Multifactor Leadership Questionnaire - MLQ (Bass and Avolio, 1997). The questionnaire examines leadership styles according to: transformational leadership (influence as an ideal personality, charisma, motivation through inspiration, intellectual stimulation, and individualized consideration), transactional leadership (contingent reward, management by exception - active, and management by exception - passive) and laissez-faire style. The questionnaire contains 36 items: four items for each factor and twenty items for transformational leadership. Answers are on a five-level scale, where $1=$ "very little", and $5=$ "to a great extent". The instrument's validity is measured by Cronbach's $\alpha$, yielding $\alpha=0.95$ for transformational leadership, and $\alpha=0.7$ for transactional leadership. 
To test the various dimensions of organizational commitment, we used the "Three-component model of commitment" questionnaire (Meyer et al., 1993). The questionnaire tests an employee's degree of commitment to the organization, according to three components: affective commitment, continuance commitment, and normative commitment. The questionnaire contains 18 closed-ended questions, with six items per factor (items $3,7,10$, and 13 are opposite items). The scale of answers is a five-level scale, where $1=$ "don't agree at all" and $5=$ "definitely agree". The instrument's validity was measured by Cronbach's $\alpha$, yielding $\alpha=0.92$ for affective commitment, and $\alpha=0.61$ for continuance commitment (after omitting item No. 2 , a total of 5 items).

To test the 'self-regulatory focus' variable we used the "General Regulatory Focus Measure" (Lockwood et al., 2002). The purpose of this instrument is to examine regulatory focus according to two sub-scales: promotion focus and prevention focus. The questionnaire contains 18 statements: nine statements for promotion focus and nine statements for prevention focus. Answers are on a 5 -level agreement scale, where $1=$ "very little" and $5=$ "very much". Instrument validity was measured by Cronbach's $\alpha$, and yielded $\alpha=0.92$ for promotion focus, and $\alpha=\mathbf{0 . 8 4}$ for prevention focus.

Demographic data were also gathered, including: gender, year of birth, family status, country of birth, year of immigration to Israel, place of residence, years of education, scope of position, seniority in organization, seniority at position and profession.

\subsection{Research Procedure}

After receiving confirmation from the managers or the commanders of the organizations, the researcher went in person to the organizations and distributed the questionnaires to the workers. Coercive organizations included: three police stations and two military bases. It was difficult to visit the prisons, and therefore the guards completed the questionnaires outside the prisons. Utilitarian organizations included: two insurance firms, a high-tech firm, and two human resources and recruitment companies. Study participants received a file of questionnaires that included the leadership style questionnaire (MLQ), organizational commitment questionnaire, regulatory focus questionnaire, and demographic questionnaire. Participants answered the questionnaires at the time they were distributed and in the presence of the researcher. Participation in the study was on a voluntary basis. Participants were guaranteed anonymity, in order to prevent distortion of their answers or discomfort. Participants were able to cease their participation in the study at any time and provided written confirmation of their voluntary participation.

\section{Results}

The present study examined the relationship between leadership style as perceived by followers (transformational, transactional), followers' organizational commitment (affective, continuance), and their regulatory focus (promotion, prevention), as moderated by organizational type (coercive, utilitarian). In order to probe the quality of the proposed model, a Structural Equation Modeling (SEM) analysis was conducted. This analysis enables investigation of complex research hypotheses, by analyzing pathways based on the idea of reconstructing matrices of original correlations using the research model. The quality of the model was assessed by the gap between the matrix received by the research model and the original correlations' matrix. The moderation hypothesis was evaluated by a multi-group moderation analysis using the $x^{2}$ test.

Table 1 shows that the mean of the 'promotion focus' variable tends toward the upper limit of the scale (3.81), and this variable's SD is the lowest among the variables (0.88), so we may infer that most of the study participants reported themselves as having a relatively high promotion focus. The affective commitment variable's SD was found to be the highest of the variables examined (1.22). In other words, followers' affective commitment is expressed differently among study participants.

Table-1. Sample size, minimum and maximum values, means and S.D. for dependent variable and independent variables

\begin{tabular}{l|l|l|l|l|l}
\hline \multicolumn{1}{l}{ Table-1. Sample size, minimum } & $\mathbf{N}$ & minimum & maximum & mean & Standard deviation \\
\hline Transformational leadership & 162 & 1.26 & 5.00 & 3.37 & .88 \\
\hline Transactional leadership & 162 & 1.25 & 5.00 & 3.11 & .89 \\
\hline Affective commitment & 162 & 1.00 & 5.00 & 3.13 & 1.22 \\
\hline Continuance commitment & 162 & 1.00 & 5.00 & 2.66 & 1.06 \\
\hline Promotion focus & 162 & 1.44 & 5.00 & 3.81 & .88 \\
\hline Prevention focus & 162 & 1.00 & 4.86 & 2.7 & .95 \\
\hline
\end{tabular}

The 'continuance commitment and 'prevention focus' variables tended toward the lower limit of the scale, 2.66 and 2.7 respectively. The $\mathrm{SD}$ of these variables is similar and relatively high, 1.06 and 0.95 respectively. Given this, we can understand that these variables are not perceived in similar fashion among the followers. There are followers who evaluated their commitment to the organization as more or less continuous and who evaluated themselves as having high or low prevention focus.

Table 2 shows a highly significant positive connection between transformational leadership and affective commitment $(r=0.66, p<.05)$ and between transformational leadership and promotion focus $(r-0.54, p<.05)$. Similarly, a highly significant positive connection was found between transactional leadership and continuance commitment $(r=0.31, p<0.05)$, and between transactional leadership and prevention focus $(r=0.31, p<.05)$. These findings confirm the assumptions made regarding them. 
Table-2. Pearson correlations between study variables

\begin{tabular}{l|l|l|l|l|l}
\hline & 1 & 2 & 3 & 4 & 5 \\
\hline 1. Transformational leadership & & & & & \\
\hline 2. Transactional leadership & .08 & & & & \\
\hline 3. Affective commitment & $.66^{* *}$ & -.07 & & & \\
\hline 4. Continuance focus & $-.24^{* *}$ & $.31^{* *}$ & $-.31^{* *}$ & & \\
\hline 5. Promotion focus & $.54^{* *}$ & .08 & $.57^{* *}$ & -.14 & \\
\hline 6. Prevention focus & $-.21^{* *}$ & $.31^{* *}$ & $-.26^{* *}$ & $.25^{* *}$ & $-.2^{*}$ \\
\hline $\mathrm{N}=169, \mathrm{p}^{*}<05, \mathrm{p}^{* *}<01$ & & &
\end{tabular}

A Structural Equation Modeling (SEM) analysis was performed using latent variables. Each latent variable was composed of appropriate questionnaire items. Items with low loading were omitted. Partial regressions were fitted between the latent variables according to the theoretical model and study hypotheses, as can be seen in Figure 1.

All regression lines in the model were found to be significant $(p<.01)$. The model fit showed partial correlation. Three out of six correlation measures were found to be above the necessary minimum, as may be seen in Table 3 .

Table-3. Model Fit

\begin{tabular}{l|l|l}
\hline Fit measure & Result & Necessary minimum \\
\hline 1. RMSEA & .054 & Less than .08 \\
\hline 2. CMIN & 1.47 & Less than 2 \\
\hline 3. CFI & .90 & Greater than .95 \\
\hline 4. NFI & .74 & Greater than .9 \\
\hline 5. CHI SQUARE $P$ & $p<.05$ & $p>.05$ \\
\hline 6. PCLOSE & .131 & Greater than .05 \\
\hline
\end{tabular}

Table 3 shows that high levels of transformational leadership predict high levels of affective commitment, $\beta=.59, p<.001$. High levels of transformational leadership also predict high levels of promotion focus, $\beta=.71$, $p<.001$, as hypothesized in Hypothesis 3.2. Furthermore, high levels of transactional leadership predict high levels of continuance commitment, $\beta=.37, p<.01$, and high levels of transactional leadership also predict high levels of prevention focus, $\beta=.40, p<.01$. These findings confirmed the hypotheses.

In order to test the hypothesis regarding the moderating influence of organization type (coercive, utilitarian) on the connection between transformational leadership and both affective commitment and promotion focus, and the connection between transactional leadership and both continuance commitment and prevention focus, a multigroup moderation examination was run using the $x^{2}$ test. A significant difference was found between groups (coercive and utilitarian) with reference to the model $(p<.01)$.

In order to test the moderating effect regarding each of the model's regression lines, $x^{2}$ tests were run for each regression line separately. Findings indicate that a marginally significant $(p<.01)$ moderating effect was found between transformational leadership and promotion focus. However, by contrast with the hypothesis, we found that in coercive organizations this connection is weaker $(\beta=.31, p<.1)$ than in utilitarian organizations $(\beta=.43, p<.01)$. Regarding the other regression lines of the model, there was no significant moderating effect for type of organization $(p>.1)$, and therefore these hypotheses were refuted.

Nevertheless, we did find a certain tendency that fits the hypotheses, in the intensity of significant connections in the different types of organizations, as follows (presented respectively): In coercive organizations the connection between transformational leadership and affective commitment was stronger $(\beta=.50, p<.01)$ than in utilitarian organizations $(\beta=.40, p<.05)$. In addition, in coercive organizations no significant connection was found between transactional leadership and continuance commitment $(\beta=.40, p>.05)$, and in utilitarian organizations this connection was significant $(\beta=.35, p<.05)$. Similarly, in coercive organizations no significant connection was found between transactional leadership and prevention focus $(\beta=.39, p>.05)$, and in utilitarian organizations this connection was found to be significant $(\beta=.33, p<.05)$.

\section{Discussion}

The present study examined the relationship between leadership styles (transformational, transactional), followers' organizational commitment (affective, continuance), and their regulatory focus (promotion, prevention), as moderated by organizational type (coercive, utilitarian).

Hypothesis No.1, which examined the connections between transactional leadership and affective commitment, was fully confirmed. In other words, the more a leader is perceived by followers as having a transformational leadership style, the more followers will feel affective commitment to the organization. This finding is consistent with the studies by Buciuniene and Skudiene (2008) who also examined the connection between transformational leadership and affective commitment, and found that there is a high correlation between these two variables. Transformational leadership positively influences a follower's affective commitment. This finding is understandable, since transformational leadership connects with affective aspects, and some even refer to this leadership style as 'emotion evoking leadership' (Popper, 1994).

Hypothesis No. 2, which examined the connection between transactional leadership and continuance commitment, was also fully confirmed. In other words, the more a leader is perceived by followers as having a transactional style, the more followers will feel continuance commitment with respect to the organization. This finding is consistent with the studies by Lo et al. (2009) who examined the connection between transactional leadership and continuance commitment. They found that the compensation dimension and active management dimension of transactional leadership are significantly connected with continuance commitment. The explanation of this finding is linked to the fact that transactional leadership is characterized by the compensation method. The leader uses an active form of management, by testing and observing workers' mistakes and correcting them 
immediately (Northouse, 2007). Therefore, it is expected that the followers' tendency will be to operate by the 'give and take' method, and when a better alternative is found, they will leave the organization for the latter.

Hypothesis No. 3, which examined the connection between transformational leadership and promotion focus, was fully confirmed. In other words, the more a leader is perceived by followers as having a transformational leadership style, the more followers will be characterized by promotion focus. Support for this may also be found in the theoretical model of Kark and Dijk (2007) which indicates that transformational leadership spurs promotion focus among followers, since it involves, among other things, ambitiousness and inspirational motivation of followers. The leader inspires ambitiousness and motivates his/her followers through inspiration, cultivating an environment focused on personal advancement in the organization, which develops the focus on followers' situational promotion.

Hypothesis No. 4, which examined the connection between transactional leadership and prevention focus, was also fully confirmed. In other words, the more a leader is perceived by followers as having a transactional leadership style, the more followers will be characterized by prevention focus. Evidence for this is found in the theoretical model of Kark and Dijk (2007) which indicates that transactional leadership arouses prevention focus, since it involves, among other things, duties and rights, preservation of the status quo and strict attention to details. The leader instills rules, responsibility, stability and avoidance of mistakes. This leadership style cultivates an environment focused on prevention of failures and mistakes which develop followers' situational prevention focus.

A model incorporating all of these connections between leadership styles, as seen by followers, and both organizational commitment and regulatory focus among followers, was examined and partially confirmed. The partial confirmation of the model may be explained as resulting from the low number of participants and the problems of subordinate affect in leader evaluations (Podsakoff and Organ, 1986; Martinko et al., 2018) in the present study. Even though the model was only partially confirmed, it can be seen that all the connections between variables were confirmed significantly.

Hypothesis 5, which examined the moderating effect of the 'organization type' variable (coercive, utilitarian) on the connections between transformational leadership and both affective commitment and promotion focus, and between transactional leadership and both continuance commitment and prevention focus, was partially confirmed. A significant difference was found between the groups with regard to the model, such that the connections between leadership styles and both organizational commitment and regulatory focus in coercive organizations differ from those in utilitarian organizations. This finding reinforces (Etzioni, 1961) typology, which classifies organizations on the basis of leaders' power and forms of identification and involvement in the organization's lowest echelon. The connections between leadership styles and forms of identification and involvement that were examined with the help of styles of organizational commitment and followers' regulatory focus do in fact operate differently in coercive as opposed to utilitarian organizations.

Nevertheless, no significant moderating effect was found for type of organization (coercive, utilitarian) on the connection between transactional leadership and prevention focus, and only a marginally significant moderating effect was found for the connection between transformational leadership and promotion focus. This marginal significance indicated that, contrary to the hypothesis that in coercive organizations this connection would be stronger than in utilitarian organizations, we found that the connection between transformational leadership and promotion focus was weaker in coercive organizations than in utilitarian organizations. This finding may be explained in several ways: The first explanation is rooted in the fact that regulatory focus includes two elements, one stable (trait) and the other situational (state) (Stam et al., 2010). It may be the case that, for study participants employed in utilitarian organizations, there is a strong stable component (trait) focused on promotion. A situational effect of rules, responsibility, stability, and avoidance of mistakes, which cultivate an environment focused on prevention of failures and mistakes, did not influence them very much. Therefore, they reported higher levels of promotion focus and/or lower levels of prevention focus. This could exist also be the case in the opposite scenario: It may be the case that study participants employed in coercive organizations have a strong, stable component (trait) focused on prevention. A situational effect of ambitiousness and inspired motivation that cultivates an environment focused on personal advancement in the organization did not influence them very much. They therefore reported lower levels of promotion focus and/or higher levels of prevention focus. Another explanation for this finding is that the considerable concentration of the transactional leader on compensation and the 'gave and take' method essentially cultivates a situational atmosphere of promotion focus but not on prevention, as hypothesized. Followers are interested in receiving compensation, and are therefore focused on promotion and attaining these things. It may be that the desire for advancement and receiving compensation in a utilitarian organization creates a higher promotion focus than ambitiousness and inspired motivation, which also cultivates a situational atmosphere of promotion focus among coercive organizations. With exception of the marginal moderation between transformational leadership and promotion focus, no significant moderating effect was found for organization type (coercive, utilitarian) in the other connections of the model.

The hypothesis regarding a connection between transformational leadership and affective commitment being stronger in coercive organizations than in utilitarian organizations was refuted. This finding may be explained through the study by Popper (1994) who found a transformational leadership style among commanders of combat units in the Israeli Defense Forces. Popper (1994) termed transactional leadership 'emotion evoking leadership', which he describes as characterized by strong emotional impact that motivates followers. Popper held that foundation of the emotional tie between the leader and his/her followers is based on the experience of lack of control and helplessness of the follower. The follower projects onto his leader desires and aspirations he/she would like to realize, so that the leader fulfills his/her fantasies and, in a sense, strengthens the ego of his subordinates. Popper (1994) wrote: "When considering situations of excessive uncertainty, a sharp sense of helplessness and lack of control, and situations perceived as difficult and directionless, primal yearning arises for a "strong man", a leader, who recreates longing for the lost Garden of Eden, for that same wonderful, lost feeling that others are concerned about me, that I can stop worrying" (Popper, 1994). Participants in the current study from coercive organizations (army, police, and prison) were sampled randomly, without categorizing participants serving in 
combat units, whose work constitutes mortal danger and who encounter situations of helplessness and lack of control, as opposed to those employed in coercive organizations in home front units, who fill positions similar to those in utilitarian organizations, such as engineers, secretaries, psychologists, and so forth. In these positions, there is practically no threat to their lives. They experience very few situations of helplessness and lack of control.

The hypothesis contending that the connection between transactional leadership and continuance commitment would prove stronger in utilitarian organizations than in coercive organizations was refuted. This finding could be explained as due to the different, diverse utilitarian organizations in which the current study's participants are employed. It seems that Etzioni (1961) typology of utilitarian organizations as profit-centered business organizations includes a very broad variety of organizations with diverse organizational cultures. An example of this can be seen in the organizational typology of the Central Bureau of Statistics. This classification is based on UN recommendations for uniform classification of economic activities (international Standard Industrial Classification) which enables classification of organizations into organizational groups that deal with close or similar activities. For example: "industry and manufacture", "information and communication"," financial services and insurance services".

The sample size, of course, influences statistical significance, and therefore constitutes a limitation in finding significance of connections between the study variables in the moderation model. It is reasonable to assume that a larger sample would have influenced the significance of the moderation model. Similarly, it is possible that in a future study there would be room to sample participants from coercive organizations, differentiating between subjects from combat units and non-combatant subjects. It is recommended that participants from utilitarian organizations be sampled from one branch, in accordance with the classification of the Central Bureau of Statistics.

The present study offers an opening into a new area in organizational research: examination of Etzioni (1961) typology for classifying organizations in the contemporary employment market. Such a study is likely to add a layer to organizational research, to the applied dimension, and to the effectiveness of organizations of the type investigated in the present study.

\section{References}

Allen, N.J. and J.P. Meyer, 1996. Affective, continuance, and normative commitment to the organization: An examination of construct validity. Journal of Vocational Behavior, 49(3): 252-276.Available at: https://doi.org/10.1006/jvbe.1996.0043.

Avolio, B.J., 1999. Full leadership development: Building the vital forces in organizations. Thousand Oaks, CA: Sage

Avolio, B.J. and B.M. Bass, 1991. The full range leadership development programs: Basic and advanced manuals. Binghamton, NY: Bass, Avolio \& Associates.

Avolio, B.J. and B.M. Bass, 2004. Multifactor leadership questionnaire. Menlo Park, CA: Mind Garden.

Banks, G.C., K.D. McCauley, W.L. Gardner and C.E. Guler, 2016. A meta-analytic review of authentic and transformational leadership: A test for redundancy. The Leadership Quarterly, 27(4): 634-652.Available at: https://doi.org/10.1016/j.leaqua.2016.02.006.

Bass, B., B. Avolio, D. Jung and Y. Berson, 2003. Predicting unit performance by assessing transformational and transactional leadership. The Journal of Applied Psychology, 88(2): 207-218.Available at: https://doi.org/10.1037/002 1-9010.88.2.207.

Bass, B.M., 1985. Leadership and performance beyond expectations. New York: Free Press.

Bass, B.M. and B.J. Avolio, 1990. Developing transformational leadership: 1992 and beyond. Journal of European Industrial Training, 14(5): 72-12.Available at: https://doi.org/10.1108/03090599010135122.

Bass, B.M. and B.J. Avolio, 1997. Full range of leadership: Manual for the multi-factor leadership questionnaire. Palto Alto, CA: Mind Garden.

Bentein, K., C. Vandenberghe, R. Vandenberg and F. Stinglhamber, 2005. The role of change in the relationship between commitment and turnover: A latent growth modeling approach. Journal of Applied Psychology, 90(3): 468-482.Available at: http://dx.doi.org.mgsariel.macam.ac.il/10.1037/002 1-9010.90.3.468.

Bernerth, J.B., M.S. Cole, E.C. Taylor and H.J. Walker, 2017. Control variables in leadership research: A qualitative and quantitative review. Journal of Management, 44(1): 131-160.Available at: https://doi.org/10.1177/0149206317690586.

Blau, P.M. and R.W. Scott, 1962. Formal organizations. San Francisco: Chandler. Book of the Rifleman Company, Operations Branch, 1950 Ed.

Bono, J.E. and T.A. Judge, 2003. Self-concordance at work: Toward understanding the motivational effects of transformational leaders. Academy of Management Journal, 46(5): 554-57 1.Available at: https://doi.org/10.2307/30040649.

Brockner, J. and E.T. Higgins, 2001. Regulatory focus theory: Implications for the study of emotions at work. Organizational Behavior and Human Decision Processes, 86(1): 35-66.Available at: https://doi.org/10.1006/obhd.2001.2972.

Buciuniene, I. and V. Skudiene, 2008. Impact of leadership styles on employees' organizational commitment in Lithuanian manufacturing companies. South East Journal of Economics and Business, 3(2): 57-66.Available at: https://doi.org/10.2478/v10033-008-0015-7.

Burns, J.M., 1978. Leadership. New York: Harper and Row.

Dumdum, U.R., K.B. Lowe and B. Avolio, 2002. A meta-analysis of transformational and transactional leadership correlates of effectiveness and satisfaction: An update and extension. In B. J. Avolio, \& F. J. Yammarino (Eds.), Transformational and charismatic leader ship: The road ahead. Oxford, U.K.: Elsevier Science, 2: 35-66.

Erkutlu, H., 2008. The impact of transformational leadership on organizational and leadership effectiveness the Turkish case. Journal of Management Development, $27(7):$ 708-726.

Etzioni, A., 1961. A comparative analysis of complex organizations. New York: Free Press.

Förster, J. and E.T. Higgins, 2005. How global versus local perception fits regulatory focus. Psychological Science, 16(8): 631-636.Available at: https://doi.org/10.1111/j.1467-9280.2005.01586.x.

Fu, W., S.P. Deshpande and X. Zhao, 2011. The impact of ethical behavior and facets of job satisfaction on organizational commitment of Chinese employees. Journal of Business Ethics, 104(4): 537-543.Available at: https://doi.org/10.1007/s 10551-011-0928-4.

Gonen, I. and E. Zakkai, 1999. Leadership and leadership development - from theory to practice. Tel Aviv, Israel: Ministry of Defense.

Griffin, M.L. and J.R. Hepburn, 2005. Side-bets and reciprocity as determinants of organizational commitment among correctional officers. Journal of Criminal Justice, 33(6): 611-625.Available at: https://doi.org/10.1016/j.jcrimjus.2005.08.010.

Gumusluoglu, L. and A. Ilsev, 2009. Transformational leadership, creativity, and organizational innovation. Journal of Business Research, 62(4): 461-473.

Higgins, E.T., 1998. Promotion and prevention: Regulatory focus as a motivational principle. Advances in Experimental Social Psychology, 1(30): 1-46.Available at: https://doi.org/10.1016/s0065-2601(08)60381-0.

Higgins, E.T., 2001. Promotion and prevention experiences: Relating emotions to None motional motivational states. In J.P. Forgas (Ed.), Handbook of affect and social cognition. Mahwah, NJ: Erlbaum. pp: 186-211.

Higgins, E.T. and I. Silberman, 1998. Development of regulatory focus: Promotion and prevention as ways of living. In J. H. C. S. Dweck (Ed.), Motivation and self-regulation across the life span. New York: Cambridge University Press. pp: 78-113.

Judge, T.A. and R.F. Piccolo, 2004. Transformational and transactional leadership: A meta-analytic test of their relative validity. Journal of Applied Psychology, 89(5): 755-768.Available at: https://doi.org/10.1037/002 1-9010.89.5.755.

Kark, R. and V.D. Dijk, 2007. Motivation to lead, motivation to follow: The role of the self-regulatory focus in leadership processes. Academy of Management Review, 32(2): 500-528.Available at: https://doi.org/10.5465/amr.2007.24351846.

Katz, D. and R.L. Kahn, 1966. The social psychology of organizations. New York: Wiley. 
Kirkbride, P., 2006. Developing transformational leaders: The full range leadership model in action. Industrial and Commercial Training, 38(1): 23-32.Available at: https://doi.org/10.1108/00197850610646016.

Koh, W.L., R.M. Steers and J.R. Terborg, 1995. The effects of transformational leadership on teacher attitudes and student performance in Singapore. Journal of Organizational Behavior, 16(4): 319-333.Available at: https://doi.org/10.1002/job.4030160404.

Kooij, D.T.A.M., P.M. Bal and R. Kanfer, 2014. Future time perspective and promotion focus as determinants of intra-individual change in work motivation. Psychology and Aging, 29(2): 319-328.Available at: 10.1037/a0036768.

Liberman, N., L.C. Idson and C.J. Camacho, 1999. Promotion and prevention choices between stability and change. Journal of Personality and Social Psychology, 77(6): 1135-1 145.Available at: https://doi.org/10.1037//0022-3514.77.6.1135.

Lo, M.C., T. Ramayah and H.W. Min, 2009. Leadership styles and organizational commitments: A test on Malaysia manufacturing industry. African Journal of Marketing Management, 1(6): 133-139.

Lockwood, P., C. Jordan and Z. Kunda, 2002. Motivation by positive or negative role models: Regulatory focus determines who will best inspire us. Journal of Personality and Social Psychology, 83(4): 854-864.Available at: https://doi.org/10.1037//00223514.83 .4 .854$.

Lord, R.G. and K.J. Maher, 1993. Leadership and information processing: Linking perceptions and performance. London: Routledge.

Lowe, K.B., K.G. Kroeck and N. Sivasubramaniam, 1996. Effectiveness correlates of transformational and transactional leadership: A metaanalytic review of the MLQ literature. The Leadership Quarterly, 7(3): 385-425.Available at: https://doi.org/10.1016/s10489843(96)90027-2.

Martin, J., 2015. Transformational and transactional leadership: An exploration of gender, experience, and institution type. Portal: Libraries and the Academy, 15(2): 331-351.Available at: https://doi.org/10.1353/pla.2015.0015.

Martinko, M.J., J.D. Mackey, S.E. Moss, P. Harvey, C.P. McAllister and J.R. Brees, 2018. An exploration of the role of subord inate affect in leader evaluations. Journal of Applied Psychology, 103(7): 738-752.Available at: https://doi.org/10.1037/aplo000302.

Mcgee, G.W. and R.C. Ford, 1987. Two (or more?) dimensions of organizational commitment: Reexamination of the affective and continuance commitment scales. Journal of Applied Psychology, 72(4): 638-641.Available at: https://doi.org/10.1037/00219010.72.4.638.

McGregor, I., M.T. Gailliot, N.A. Vasquez and K.A. Nash, 2007. Ideological and personal zeal reactions to threat among people with high self-esteem: Motivated promotion focus. Personality and Social Psychology Bulletin, 33(11): 1587-1599.Available at: https://doi.org/10.1177/0146167207306280.

Meindl, J.R., 1995. The romance of leadership as a follower-centric theory: A social constructionist approach. The Leadership Quarterly, 6(3): 329-341.Available at: https://doi.org/10.1016/1048-9843(95)90012-8.

Meyer and Allen's, 1991. Three-component model of organizational commitment. Journal of Applied Psychology, 79(1): 15-23.Available at: http://dx.doi.org.mgsariel.macam.ac.il/10.1037/0021-9010.79.1.15.

Meyer, J.P., N.J. Allen and C.A. Smith, 1993. Commitment to organizations and occupations: Extension and test of a three-component conceptualization. Journal of Applied Psychology, 78(4): 538-551.

Mintzberg, H., 1979. The structuring of organizations. Englewood Cliffs, NJ: Prentice-Hall. pp: 81-95.

Mowday, R.T., L.W. Porter and R.M. Steers, 1982. Employee-organization linkages. New York: Academic Press.

Neubert, M.J., M.K. Kacmar, D.S. Carlson, L.B. Chonko and J.A. Roberts, 2008. Regulatory focus as a mediator of the influence of initiating structure and servant leadership on employee behavior. Journal of Applied Psychology, 93(6): 1220-1233.Available at: https://doi.org/10.1037/a0012695.

Northouse, P.G., 2007. Leadership: Theory and practice. 4th Edn., Thousand Oaks, CA: Sage.

Piccolo, R.F. and J.A. Colquitt, 2006. Transformational leadership and job behaviors: The mediating role of core job characteristics. Academy of Management Journal, 49(2): 327-340.Available at: https://doi.org/10.5465/amj.2006.20786079.

Podsakoff, P.M. and D.W. Organ, 1986. Self-reports in organizational research: Problems and prospects. Journal of Management, 12(4): 531 544.

Popper, M., 1994. Combat leadership in the IDF and leadership in business organizations - comparison and significance. [Heb.] Pituach Irguni b'Israel, 2(6): 11-19.

Popper, M., 1994. The influence of leaders. On managers as leaders. Israel: Tel Aviv University. pp: 53-54.

Popper, M., 2012. Fact and fantasy about leadership. Northampton, MA: Edward Elgar.

Rhoades, L. and R. Eisenberger, 2002. Perceived organizational support: A review of the literature. Journal of Applied Psychology, 87(4): 698-7 14.Available at: https://doi.org/10.1037//0021-9010.87.4.698.

Riketta, M., 2002. Attitudinal organizational commitment and job performance: A meta-analysis. Journal of Organizational Behavior: The International Journal of Industrial, Occupational and Organizational Psychology and Behavior, 23(3): 257-266.Available at: http://dx.doi.org.mgs-ariel.macam.ac.il/10.1002/job.141.

Rusbult, C.E. and D. Farrell, 1983. A longitudinal test of the investment model: The impact on job satisfaction, job commitment, and turnover of variations in rewards, costs, alternatives, and investments. Journal of Applied Psychology, 68(3): 429-438.Available at: https://doi.org/10.1037/0021-9010.68.3.429.

Samuel, I., 2012. Organizations: Introduction to the theory of organizations. 3rd Edn., Haifa. Israel: Zmora-Bitan. pp: 19-55.

Seibt, B. and J. Förster, 2004. Stereotype threat and performance: How self-stereotypes influence processing by inducing regulatory foci. Journal of Personality and Social Psychology, 87(1): 38-56.Available at: https://doi.org/10.1037/0022-35 14.87.1.38.

Stam, D., D. van Knippenberg and B. Wisse, 2010. Focusing on followers: The role of regulatory focus and possible selves in visionary leadership. The Leadership Quarterly, $21(3)$ : 457-468.Available at: https://doi.org/10.1016/j.leaqua.2010.03.009.

Walumbwa, F.O. and J.J. Lawler, 2003. Building effective organizations: Transformational leadership, collectivist orientation, work-related attitudes and withdrawal behaviours in three emerging economies. International Journal of Human Resource Management, 14(7): 1083-1101.Available at: https://doi.org/10.1080/0958519032000114219.

Yammarino, F.J., W.D. Spangler and B.M. Bass, 1993. Transformational leadership and performance: A longitudinal investigation. The Leadership Quarterly, 4(1): 81-102.Available at: https://doi.org/10.1016/1048-9843(93)90005-e. 